\title{
THE EFFECT OF BOVINE SERUM AND EGG ALBUMIN ON THE GROW'TH OF ACID FAST BACILLUS*
}

\section{Effect of bovine albumin fraction $V$ on the growth of acid fast bacillus and some experiments for determination of the mechanism of its promoting effect}

\author{
MASAHIRO NAKAMURA \\ Department of Bacteriology,** Kurume University School \\ of Medicine, Kurume-shi, Japan
}

\begin{abstract}
In the previous reports (1) (2) (3), the effect of bovine serum and egg albumin on the growth of Mycobacleriun phle; has been investigated by electrophoresis using a Tiselius apparatus. The results obtained demonstrated that these proteins which promote the growth of the organisms acted as catalytic or protective rather than nutritive growth factors, because the quantitative and qualitative changes of albumin in the media after ten days of inoculation of Mycobacterium phlei was not observed by means of electrophoretic patterns. This paper reports the effect of bovine albumin fraction $\mathrm{V}$ on the growth of Mycobacterium phlei and BCG, observation on the mechanism of the stimulating effect of the albumin, and furthermore, describes whether this electrophoretic method would be reasonable or not for the determination of mechanism of the promoting effect of albumin on the growth of acid fast bacilli.
\end{abstract}

\section{MATERIALS AND METHODS}

Bacterial strairs. A saprophytic acid fast bacillus, Mycobacterium phlei, and a slowly growing bacillus, $B C G$, were employed in all experiments. The bacterial suspensions were prepared with physiological saline solution.

Media and Proteins used. The basic media used in the experiments were Kirchner's and slightly modified Kirchner's media. These compositions were as follows :

\footnotetext{
* Aided by a grant for scientific research from the Japan Ministry of Education.

** Director: Prof. Y. Nakagawa, M. D.
} 


\begin{tabular}{|c|c|}
\hline \multirow[t]{7}{*}{ Basic medium; } & $\mathrm{Na}_{2} \mathrm{HPO}_{4}$ \\
\hline & $\mathrm{KH}_{2} \mathrm{PO}_{4}$ \\
\hline & Mag. sulf. : $0.6 " \prime$ \\
\hline & Nat. citric. \\
\hline & Asparagine \\
\hline & Glycerine (Specific gravity, 1.2) \\
\hline & Distilled water \\
\hline A-medium; & $\begin{array}{l}\text { Asparagin contained in the basic medium } \\
\text { was decreased in order of } 2 \text {-fold dilutions. }\end{array}$ \\
\hline B-medium; & $\begin{array}{l}\text { Glycerine contained in the basic medium } \\
\text { was decreased in order of } 2 \text {-fold dilutions. }\end{array}$ \\
\hline $\mathrm{C}$-medium; & $\begin{array}{l}\text { Both asparagine and glycerine contained in } \\
\text { the basic medium were decreased in order } \\
\text { of } 2 \text {-fold dilutions. }\end{array}$ \\
\hline
\end{tabular}

Bovine serum, crystalline egg albumin (Merck Co.), and bovine albumin fraction V (Armour Co.) were employed. These albumins except bovine serum were dissolved into the media above mentioned in desirable concentration, and the media containg these albumin proteins were sterilized through Asbest filter. $5 \mathrm{ml}$ of these media were poured aseptically into each sterilized culture tube.

The concentrations of egg and fraction $\mathrm{V}$ albumins to be added to the media were determined before experiment by electrophoretic patterns, so that the volume of the albumins possessed the equal area to that of albumin peak in 10 per cent bovine serum: the concentration of egg albumin added to media was 1.0 per cent, and bovine albumin fraction $\mathrm{V} 0.5$ per cent.

Electrophoresis. As shown in the previous report (3), the media before use and filtered media after propagation of the bacilli, were used as the samples for electrophoresis by Tiselius method using a micro-Tiselius apparatus. Undiluted samples were dialyzed in $\mathrm{M} / 10$ phosphate buffer of $\mathrm{pH} 8.2$ for more than 16 hours in an ice box. Electrophoresis was carried out at $10 \mathrm{C}$ to $16 \mathrm{C}$ in water bath for 60 minutes, with a constant current of 6 to $8 \mathrm{~mA}, 80$ volt. The electrophoretic patterns of both ascending and descending boundaries were photographed at $\theta=55$ of diagonal slit angle, and the areas of peaks were estimated by magnifying the patterns by 5 times on the section paper. The rate of albumin area to total area was also determined by the patterns thus magnified but the area of egg albumin and bovine albumin fraction $\mathrm{V}$ were indicated as absolute value. In these 
experiments, the effect of albumin fraction alone in bovine serum as the previous reports was observed and globulin fraction was not examined.

Nitrogen content. The nitrogen content of the media was measured by the micro-Kjeldahl method as the consumed dose of nitrogen source, asparagine, which was consumed during the growth of bacilli.

Evaporation residue (4). The residue of evaporation of the media before use and filtered media after propagation of the bacilli was meansured as the dose of carbonic source, glycerine, consumed during propagation of the bacilli. The theoretical evaporation residue of the media before use was 0.63 grams per $20 \mathrm{ml}$ of culture medium.

General. $\quad 10^{-5} \mathrm{mg}$ of moist cells of Mycobacterium phlei, and $10^{-3} \mathrm{mg}$ of moist cells of $B C G$ were inoculated into each culture tube. All tubes were then incubated at $37 \mathrm{C}$ and examined the $\mathrm{pH}$ values of media, weights of dry cells, nitrogen contents, evaporation residue, and electrophoretic patterns of the media after desiable culture days.

As the control experiment, uninoculated culture media were treated similarly to the cultured media above mentioned.

TABLE 1

Effect of bovine albumin fraction V (Armour Lab.) on the growth of Myc. phlei

\begin{tabular}{|c|c|c|c|c|c|c|c|}
\hline Exp. & $\begin{array}{l}\text { Culture } \\
\text { days }\end{array}$ & 2 & 4 & 6 & 8 & 10 & 12 \\
\hline \multirow{4}{*}{ Exp. } & $\mathrm{pH}$ & 6.6 & 7.2 & 7.3 & 7.6 & 7.8 & 8.2 \\
\hline & $\begin{array}{l}\text { Weights of* } \\
\text { dry cells }\end{array}$ & 1.8 & 133 & 24.2 & 37.0 & 87.2 & 38.9 \\
\hline & \multirow[t]{2}{*}{$\begin{array}{l}\text { Patterns of } \\
\text { Electro- } \\
\text { phoresis }\end{array}$} & Men in & $\sqrt{280}$ & Exis as & Fins: & Eun & \\
\hline & & $172 / 173^{* *}$ & $189 / 179$ & $200 / 219$ & 172,179 & $228 / 222$ & $186 / 179$ \\
\hline \multirow{3}{*}{ Cont. } & $\mathrm{pH}$ & 6.4 & 6.6 & 6.6 & 6.8 & 6.8 & 6.6 \\
\hline & \multirow[t]{2}{*}{$\begin{array}{l}\text { Patterns of } \\
\text { Electro- } \\
\text { phoresis }\end{array}$} & 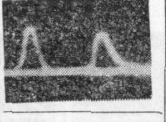 & rextis & 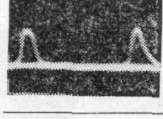 & 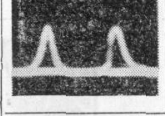 & & \\
\hline & & $174 / 171$ & $180 / 161$ & $165 / 135$ & $157 / 165$ & $176 / 187$ & $177 / 179$ \\
\hline
\end{tabular}

* $\mathrm{Mg}$ per $5 \mathrm{ml}$ of culture medium.

** The area of ascending peak/The area of descending peak. 


\section{RESULTS}

Effect of bovine albumin fraction $V$ on the growth of Mycobacterium phlei. The weights of dry cells of Mycobacterium phlei propagated in the media, $\mathrm{pH}$ values of the media, and albumin fraction $\mathrm{V}$ areas which calculated from electrophoretic pattern, are summerized in Table 1. It was indicated that the weights of dry cells increased until the 10th culture day and thereafter decreased, and that no significant difference in the values of the area of albumin fraction $\mathrm{V}$ with a danger rate below 5 per cent was observed between the experimental and the control materials.

TABLE 2

Growth of Mycobacterium phlei in the modified Kirchner's media

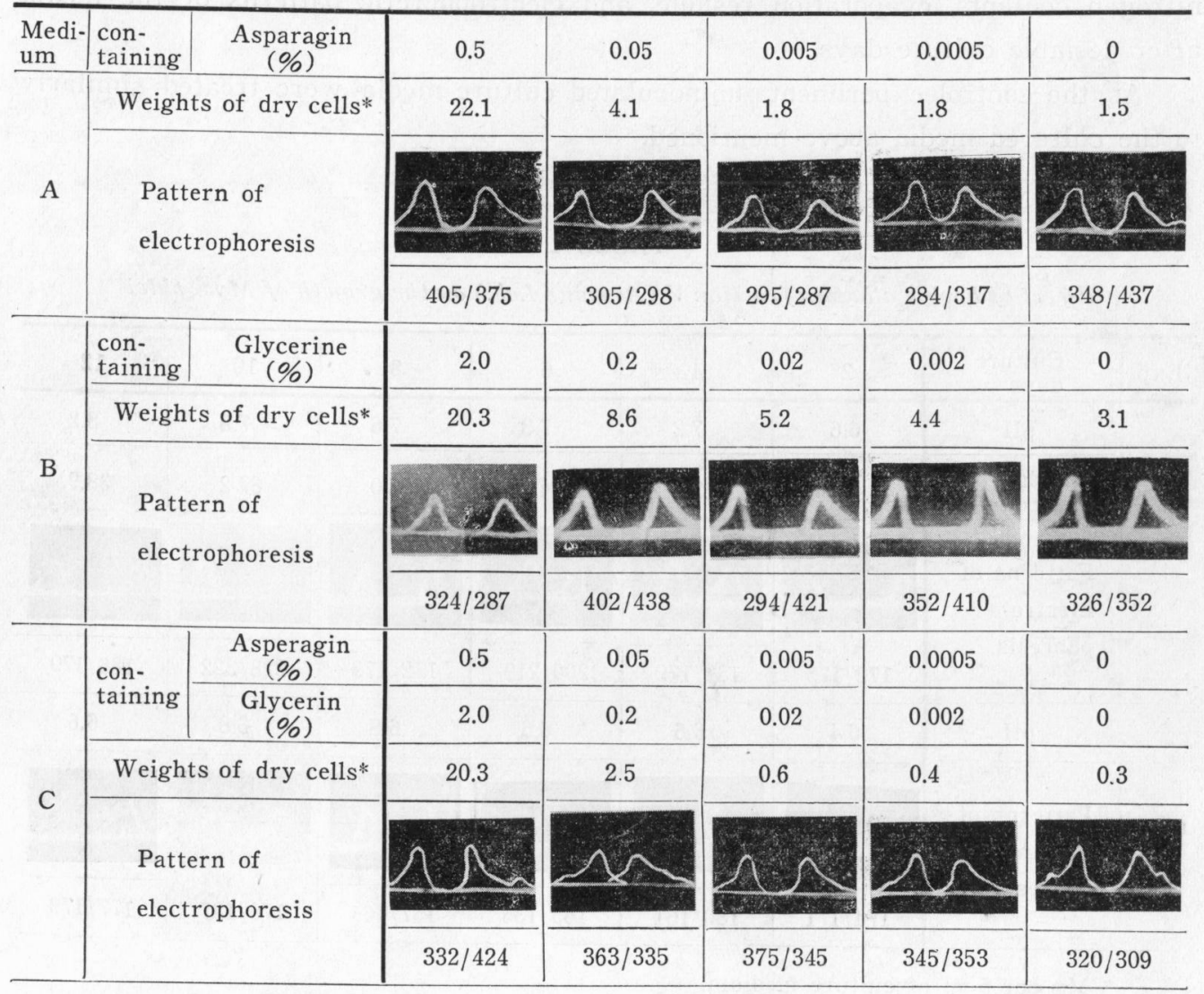

* Growth recorded at 7 days, $\mathrm{mg}$ per $5 \mathrm{ml}$ of culture medium. 
Effect of egg albumin on the growth of Mycobacterium phlei in modified Kirchner's media. Effect of egg albumin on the growth of Mycobacterium phlei was tested in the A-, B-, and C- medium mentioned in the experimental methods. These media contained 1.0 per cent of egg albumin with various concentrations of food sources. As shown in Table 2, the weights of dry cells were influenced by the concentration of food source, especially nitrogen contained in the media but the concentrations of albumin did not make any significant influence on the cell weights.

Effect of various albumin concentrations on the growth of Mycobacterium phiei. Egg albumin and bovine albumin fraction $\mathrm{V}$ added to the basic media in order of 2 -fold dilutions.

The weights of dry cells propagated in these media were measured after 7 days of inoculation. The results obtained are shown in Table 3 . The results indicated that the effective concentration of egg albumin to promote the growth of bacilli was 0.5 per cent and over and that of bovine albumin fraction $V$ was 0.01 per cent and over and that especially 0.5 per cent of egg albumin and 0.05 per cent of bovine albumin fraction $\mathrm{V}$ stimulated markedly the growth of $M y_{c o-}$ bacterium phlei. The results obtained above are summerized in Fig. 1.

TABLE 3

Growth of Mycobacterium phlei in the media containing various concentrations of egg albumin and bovine albumin fraction $V$

\begin{tabular}{|c|c|c|c|c|c|c|c|c|}
\hline \multirow{4}{*}{ 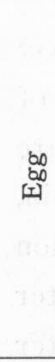 } & $\begin{array}{c}\text { Albumin } \\
(\%)\end{array}$ & 1.0 & 0.5 & 0.1 & 0.05 & 0.01 & 0.005 & 0 \\
\hline & \multirow{2}{*}{$\begin{array}{l}\text { Pattern of } \\
\text { electro- } \\
\text { phoresis }\end{array}$} & & & & & & & \\
\hline & & $577 / 295$ & $259 / 215$ & $104 / 109$ & 49 & & & \\
\hline & $\begin{array}{l}\text { Weights of* } \\
\text { dry cells }\end{array}$ & 23.0 & 25.5 & 23.5 & 12.0 & 11.5 & 11.3 & 11.0 \\
\hline \multirow{4}{*}{ 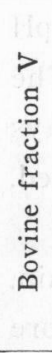 } & $\underset{(\%)}{\text { Albumin }}$ & 0.5 & 0.1 & 0.05 & 0.01 & 0.005 & 0.001 & 0 \\
\hline & \multirow{2}{*}{$\begin{array}{l}\text { Pattern of } \\
\text { electro- } \\
\text { phoresis }\end{array}$} & & & & & & & \\
\hline & & $222 / 220$ & $36 / 38$ & $21 / 18$ & & & & \\
\hline & $\begin{array}{l}\text { Weights of } \\
\text { dry cells }\end{array}$ & 25.2 & 28.4 & 35.7 & 0.73 & 12.0 & 12.0 & 11.0 \\
\hline
\end{tabular}

* Growth recorded at 7 days, $\mathrm{mg}$ per $5 \mathrm{ml}$ of culture media. 


\section{Figure 1.}

Growth of Mycobacterium phlei in the media containing various concentrations of albumin and food sources.

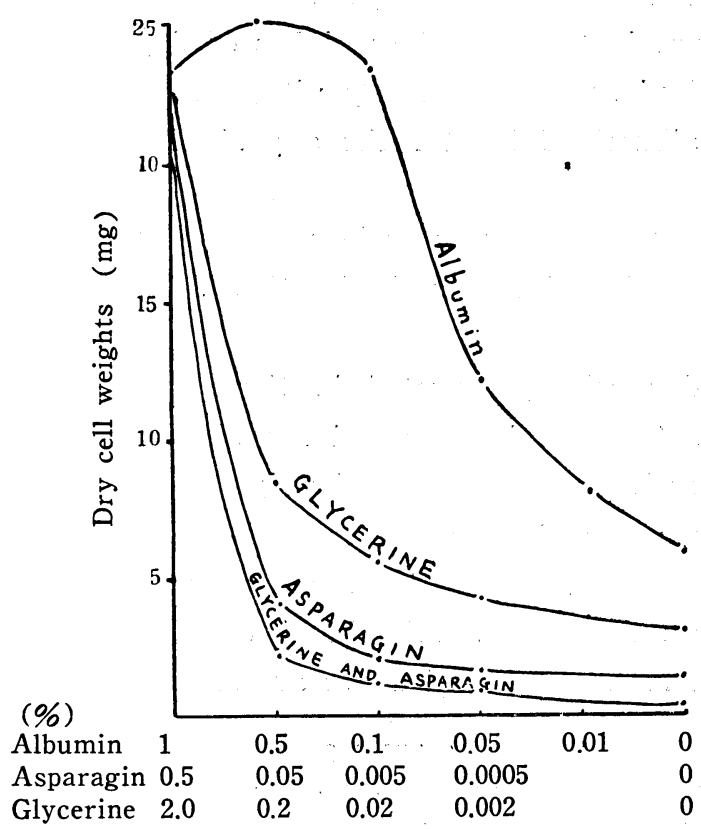

Further experiments on effect of albumin on the growth of Mycobacterium phlei. This experiment was carried out as follows: After measurement of nitrogen contents and evaporation residue of the basic and albumin added culture media before use, the bacterial suspensions were inoculated into the same media, and $\mathrm{pH}$ values of the medium, weights of dry cells, nitrogen contents, evaporation residue of culture media, and electrophoretic patterns of the filtered media after 10 days of cultivation of Mycobacterium phlei were examined. Supplying water and foods which were consumed by growth of the bacilli, and adjusting of $\mathrm{pH}$ value of the media at 7.0, the media were sterilized through Asbest filter. The bacilli were then inoculated into those prepared media. After additional 10 days of inoculation, the weights of dry cells propagated in the media were measured. The results obtained are shown in Table 4 .

It was noted that the electrophoretic patterns of bovine serum, egg albumin, and bovine albumin fraction $\mathrm{V}$ in the media tested; was no difference among before inoculation, after 10 days, and after additional 10 days of inoculation of the bacilli. 
The weights of dry cells of the media which were supplyed with foods consumed during the growth were the same as those of the fresh media of control except the egg albumin group, while those of the media not supplyed with foods were markedly reduced compared with those of the control.

Effect of various albumin concentrations on the growth of BCG. A BCG suspension was inoculated into the media containing various albumin concentrations (See Table 5). After four weeks of inoculation, the electrophoretic patterns of filtrated media and weights of dry cells of $B C G$ were examined. The results are shown in Table 5. The results demonstrated that the concentration of egg albumin and bovine fraction $\mathrm{V}$ to be effective on the growth of $B C G$ was 0.1 and 0.05 per cent, but, in latter, even 0.0005 per cent of bovine albumin fraction $\mathrm{V}$ was proved to promoted slightly the growth of $B C G$. This concentration of albumin fraction $\mathrm{V}$ is too little to observe by electrophoresis using a micro-Tiselius apparatus. Therefore, the results, thus obtained, would not be so reliable for the consideration of effect of bovine albumin fraction $\mathrm{V}$ on the growth of $B C G$.

The growth of BCG in the media containing heated serum, egg, and bovine albumin fraction $V$. The sterilized, through Asbest filter, media containing 10 per cent bovine serum, 1.0 per cent egg albumin, and 0.5 per cent bovine albumin fraction $\mathrm{V}$ were heated at $65 \mathrm{C}, 70 \mathrm{C}, 80 \mathrm{C}$, and at $100 \mathrm{C}$ respectively in the water bath for 60 minutes. Though such concentration of albumins did not markedly promote the growth of $B C G$, it was suitable concentration for observation by a Tiselius apparatus. A $B C G$ suspension was inoculated into these media, and the media were incubated at $37 \mathrm{C}$. The electrophoretic patterns and the weights of dry cells after four weeks of inoculation are shown in Table 6 . The growth of $B C G$ was promoted in the medium containing albumin which was not heated except the egg albumin group. In the egg albumin group, when the albumin was heated at $70 \mathrm{C}$, slight stimulation of the growth of the bacilli was observed.

The albumin pattern in whole bovine serum was changed by heating, and finally was almost destroyed at $70 \mathrm{C}$. This would indicate that the albumin fraction was completely destroyed at $80 \mathrm{C}$ and over, and at the same time that the stimulating effect of albumin on the growth of $B C G$ was lost. The changes of egg and bovine albumin fraction $\mathrm{V}$ patterns observed by a Tiselius apparatus were not determined. 
TABLE 4

Growth of Mycobacterium phlei in the media which were supplemented foods consumed during the growth of the bacilli and in the media without supplement of foods consumed

\begin{tabular}{|c|c|c|c|c|c|c|c|c|}
\hline & \multicolumn{2}{|c|}{$\begin{array}{l}\text { Before inoculation } \\
\text { of bacteria }\end{array}$} & \multirow{2}{*}{$\begin{array}{l}\text { After } 10 \\
\text { day of } \\
\text { cultivation } \\
\text { of } \\
\text { Myc. phlei }\end{array}$} & & \multicolumn{3}{|c|}{$\begin{array}{l}\text { After additional } 10 \text { day of } \\
\text { cultivation of Myc. phlei }\end{array}$} \\
\hline & & $\begin{array}{l}\text { Basic } \\
\text { Kirch- } \\
\text { ner }\end{array}$ & $\begin{array}{l}\text { Basic Kirch- } \\
\text { ner added } \\
\text { serum }\end{array}$ & & & $\begin{array}{l}\text { Medium } \\
\text { supplied } \\
\text { foods }\end{array}$ & $\begin{array}{l}\text { Medium } \\
\text { consumed } \\
\text { foods }\end{array}$ & $\begin{array}{l}\text { Fresh } \\
\text { medium }\end{array}$ \\
\hline \multirow{6}{*}{ 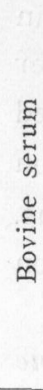 } & $\mathrm{pH}$ & & 7.0 & 8.0 & \multirow{18}{*}{ 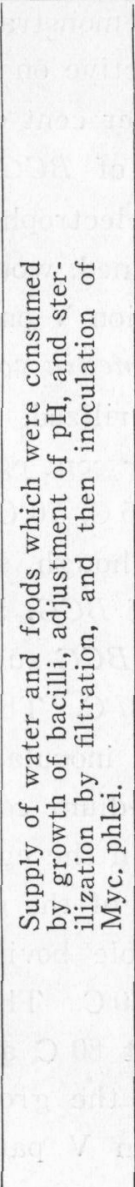 } & 8.2 & 8.2 & 7.9 \\
\hline & $\mathrm{N} \mathrm{mg} / \mathrm{ml}$ & 0.85 & 1.67 & 0.84 & & & & \\
\hline & Glycerine & $5.19 \%$ & $6.00 \%$ & $0.21 \%$ & & & & \\
\hline & $\begin{array}{l}\text { Electro- } \\
\text { phoresis }\end{array}$ & & MUNa & NAn & & & & \\
\hline & & ** & $0.31 ; 0.39$ & $0.29 ; 0.33$ & & & & \\
\hline & $\begin{array}{l}\text { Weight of } \\
\text { dry cells }\end{array}$ & & & 290.0 & & 239.0 & 1.0 & 238.0 \\
\hline \multirow{6}{*}{ 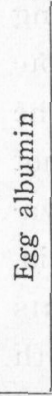 } & $\mathrm{pH}$ & & 7.0 & 7.9 & & 7.5 & 7.9 & 7.9 \\
\hline & $\mathrm{N} \mathrm{mg} / \mathrm{ml}$ & 0.85 & 1.47 & 0,72 & & & & t. \\
\hline & Glycerine & $5.19 \%$ & $6.65 \%$ & $0.16 \%$ & & & & \\
\hline & $\begin{array}{l}\text { Electro- } \\
\text { phoresis }\end{array}$ & & A. & Ana & & & & \\
\hline & & $* * *$ & $1001 ; 868$ & $1142 ; 1142$ & & & & \\
\hline & $\begin{array}{l}\text { Weight of } \\
\text { dry cells\# }\end{array}$ & & & 332.0 & & 126.0 & 4.5 & 242.0 \\
\hline \multirow{6}{*}{ 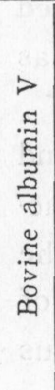 } & $\mathrm{pH}$ & 6.8 & 6.6 & 7.7 & & 7.2 & 7.8 & 7.8 \\
\hline & $\mathrm{N} \mathrm{mg} / \mathrm{ml}$ & 0581 & 0.815 & 0.579 & & & & \\
\hline & Glycerine & $6.41 \%$ & $7.23 \%$ & $2.25 \%$ & & & & \\
\hline & $\begin{array}{l}\text { Electro- } \\
\text { phoresis }\end{array}$ & & A. & A. & & & & \\
\hline & & $* * *$ & $173 ; 190$ & $176 ; 187$ & & $121 ; 116$ & $140 ; 111$ & $186 ; 191$ \\
\hline & $\begin{array}{l}\text { Weight of* } \\
\text { dry cells }\end{array}$ & & & 38.6 & & 23.7 & 2.0 & 22.8 \\
\hline
\end{tabular}

$\dagger$ The dose of glycerine is indicated as evaporation residue.

\# $\mathrm{Mg}$ per $30 \mathrm{ml}$ of culture media.

* $\mathrm{Mg} 5 \mathrm{ml}$ of culture media.

** A rate of albumin area to total protein area.

*** Ascending area; descending area. 
TABLE 5

Growth of $B C G$ in the media containing various concentrations of albumin proteins

\begin{tabular}{|c|c|c|c|c|c|c|c|c|c|c|c|}
\hline \multicolumn{2}{|c|}{$\underset{(\%)}{\text { Albumin }}$} & 1.0 & 0.5 & 0.1 & 0.05 & 0.01 & 0.005 & 0.001 & 0.0005 & 0.0001 & 0 \\
\hline \multirow{2}{*}{ Egg } & $\begin{array}{l}\text { Electro- } \\
\text { phoresis }\end{array}$ & $577 / 295$ & $259 / 215$ & $104 / 109$ & 49 & & & & & & \\
\hline & $\begin{array}{l}\text { Weights of* } \\
\text { dry cells }\end{array}$ & 0 & 0 & 0.5 & 0.3 & 0 & 0 & 0 & & & 0 \\
\hline \multirow{2}{*}{$\begin{array}{l}\text { Bovine } \\
\text { frac- } \\
\text { tion V }\end{array}$} & $\begin{array}{l}\text { Electro- } \\
\text { phoresis }\end{array}$ & & $222 / 220$ & $36 / 38$ & $21 / 18$ & & & & & & \\
\hline & $\begin{array}{l}\text { Weights of } \\
\text { dry cells* }\end{array}$ & & 10.0 & 42.7 & 45.0 & 32.0 & 7.1 & 2.3 & 0.4 & 0 & 0 \\
\hline
\end{tabular}

* $\mathrm{Mg}$ per $5 \mathrm{ml}$ of the media after 4 weeks of inoculation.

TABLE 6

Growth of $B C G$ in the media containing various treated bovine serum and albumin proteins

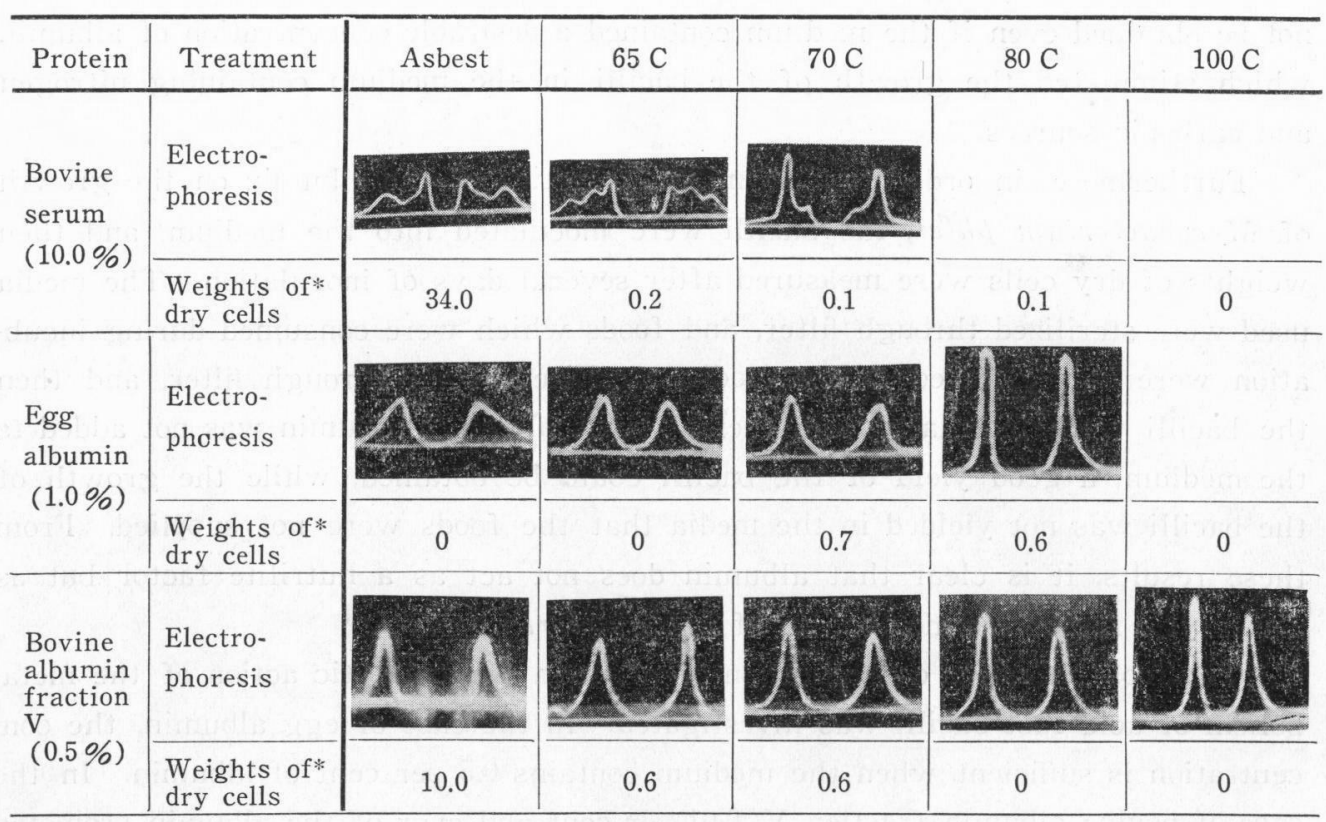

* Mg per $5 \mathrm{ml}$ of the media after 4 weeks of inoculation. 


\section{DISCUSSION}

Davis \& Dubos (9) assumed at first that albumin, like most known growth factors, contributed as a nutrilite which was absorbed by the tubercle bacilli. After further studies on the mechanism of action of albumin, however, they (6) -(13) reported that albumin acted as a protective and catalytic factor for growth of tubercle bacilli and that each molecule of albumin binded with 3 to 6 molecules of oleic acid tightly enough to prevent bacteriostatis.

On the other hand, the results obtained in our laboratory, as previous reported, explained that the action of albumin fraction on the growth of Mycobacterium phle $i$ was a catalytic effect for growth of the bacilli, because the change of electrophoretic pattern of albumin fraction was not recognized by observation using a Tiselius apparatus even when the abundant growth of the bacilli was yielded. The results described in the present paper show the same as above. In this report. the experiments were carried out by using Mycobacterium phlei and BCG. Namely, the yield of Mycobacterium phlei depended upon the dose of food sources especially nitrogen source, and not upon the concentration of albumin fraction. A good yield of Mycobacterium phlei in the medium except food sources could not be obtained even if the medium contained a desirable concentration of albumin which stimulated the growth of the bacilli in the medium containing nitrogen and carbonic sources.

Furthermore, in order to determine the action of the albumin on the growth of Mycobacterium phlei, the bacilli were inoculated into the medium, and then weights of dry cells were measured after several days of inoculation. The media used were sterilized through filter, and foods which were consumed during incubation were supplemented to the media, sterilized again through filter, and then the bacilli were inoculated into them. Thus, although albumin was not added to the medium, a good yield of the bacilli could be obtained, while the growth of the bacilli was not yielded in the media that the foods were not supplied. From these results, it is clear that albumin does not act as a nutrilite factor but as a catalytic factor for metabolism of Mycobacterium phlei.

The most effective concentration of albumin for catalytic action of the metabolism of acid fast bacilli was investigated. In the case of egg albumin, the concentration is sufficient when the medium contains 0.5 per cent of albumin. In the case of bovine albumin fraction V, 0.01 per cent and over of the albumin promoted in high degree the growth of acid fast bacilli. Since this concentration of egg 
albumin could be observed by electrophoresis using a Tiselius apparatus, it is thought that the electrophoretic procedure employed is a sufficient method for observation of change of albumin which is added to culture media.

However, in the case of $B C G$ which grow so slowly, this finding was different to that of Mycobacterium phlei. The most effective concentration of albumin to be added to the media for promoting the growth of $B C G$ was 0.1 per cent of egg albumin or 0.05 to 0.1 per cent of bovine albumin fraction V. These concentrations of albumin can not be observed by electrophoresis using a Tiselius apparatus, therefore, it is not suitable to use a Tiselius apparatus for determination of change of albumin in the media with the growth of $B C G$.

The bovine albumin fraction $\mathrm{V}$ more enhanced the growth of $B C G$ than egg albumin. This observation was partially in agreement with that of Dubos (12), and was contrary to that of Youmans (5). The promoting effect of bovine serum, and bovine albumin fraction $\mathrm{V}$ were lost by heating except egg albumin. The effect of egg albumin enhanced by heating at $70 \mathrm{C}$ and $80 \mathrm{C}$. It is considered that egg albumin contains a inhibitor for growth of tubercle bacilli and the heat stable impurities which increase merkedly the growth of tubercle bacilli in synthetic media (10).

It was not cleared that bovine serum, egg albumin, and bovine albumin fraction $\mathrm{V}$ did not enhanced the growth of acid fast bacilli in the same degree, while three media contained the same concentration of albumin fraction measured by observation of using a Tiselius apparatus.

\section{SUMMARY}

The promoting effects of bovine serum, egg albumin, and bovine albumin fraction $\mathrm{V}$ on the growth of Mycobacterium phlei and $B C G$ were investigated by electrophoretic method using a micro Tiselius apparatus. No change of these albumin in the media both before use and after propagation of the bacilli was recognized. Therefore, it was concluded that the effects of these albumins were the catalytic actions for the growth of acid fast bacilli.

In the case of $B C G$, however, the most enhancing concentration of albumin on the growth of $B C G$ was confirmed to be 0.01 per cent. As this concentration of albumin could not be observed by electrophoresis pattern using a Tiselius apparatus, further investigation for studying on effect of albumin on the growth of $B C G$ should be carried out in another way. 


\section{ACKNOWLEDGMENT}

The author wished to express with gratitude to Professor Y. NAkAgawa for the direction and advice he has given during the progress of this work.

\section{REFERENCES}

1) Nakamura, M.: The effect of the serum fractions on the growth of acid fast bacilli. I. Effect of the bovine serum on the growth of acid-fast bacilli. Medicine and Biology, Vol. 27, 246-250, 1953. (in Japanese).

2) Nakamura, M.: The effect of the serum fractions on the growth of acid fast bacilli. II. The effect of egg-albumin on the growth of acid fast bacilli. Medicine and Biology, Vol. 26, 6062, 1953 (in Japanese).

3) Nakamura, M.: The effect of bovine serum and egg albumin on the growth of acid fast bacillus. I. The effect of bovine serum and egg albumin on the growth of acid fast bacillus. Kurume Med. J., Vc1. 1, 90-98, 1954.

4) Asami, N., et al : Biochemical studies of filtrated media and bacterial cells of tubercle bacilli in the liquid media. I. Kekkaku (Tuberculosis), Vol. 27, 246-249, 1952. (in Japanese).

5) Youmans, A. S., and Youmans, G, P.: The effect of bovine plasma fractions on the growth of Myc. tuberculosis var. hominis. J. Bact.,Vol. 60, 561-568, 1950.

6) Doвоs, R. J.: Rapid and submerged growth of Mycobacteria in liquid media. Proc. Soc. Exp. Biol. \& Med., Vol. 58, 361-362, 1945.

7) Dobos, R. J., and Middlebrook, G.: The effect of wetting agents on the growth of tubercle bacilli. J. Exp. Med., Vol. 88, $81-88,1948$.

8) Dubos, R. J.: The effect of lipids and serum albumin on the bacterial growth. J. Exp. Med., Vol. 85, 9-22, 1947.

9) Davis, B. D., and Dubos, R. J.: The binding of fatty acids by serum albumin a protective growth factor in bacieriological media. J. Exp. Med., Vol. 86, 215-228, 1947.

10) Dubos, R. J., and Davis, B. D.: Factors affecting the growth of tubercle bacilli in liquid media. J. Exp. Med., Vol. 83, 409-423, 1946.

11) Dubos, R. J.: Effect of long certain fatty acids on bacterial growth. Proc. Soc. Exp. Biol. \& Med., Vol. 63, 56-58, 1946.

12) Davis, B. D., and Dubos, R. J.: The inhibitory effect of lipase on bacterial growth in media containing fatty acid ester. J. Bact., Vol. 55, 11-23, 1948.

13) Dubos, R. J., Davis, B. D., Middlebrook, G., and Pierce, C.: The effect of water soluble lipoid in the growth and biological properties of tubercle bacilli. Amer. Rev. Tub., Vol. 54, 204$212,1946$. 